BAREKENG: Jurnal Ilmu Matematika dan Terapan

June 2021

Vol. 15 No. 2

Page 257-266

P-ISSN: 1978-7227 E-ISSN: 2615-3017

\title{
APLIKASI PERSAMAAN DIFERENSIAL STOKASTIK PADA MASALAH KONTROL OPTIMUM BERKENDALA
}

\section{Application of Stochastic Differential Equation in Constrained Control Optima Problems}

\author{
Meliana Pasaribu ${ }^{1}$, Helmi $^{2 *}$ \\ 1,2 Prodi Matematika, Fakultas Matematika dan Ilmu Pengetahuan Alam, Universitas Tanjungpura \\ Jln. Prof. Dr. H. Hadari Nawawi, Pontianak, 78124, Indonesia
}

Corresponding authore-mail: ${ }^{2 *}$ helmi@math.untan.ac.id

\begin{abstract}
Abstrak
Penyebaran Covid-19 dapat dikontrol dengan mengkarantina populasi yang terinfeksi Covid-19 atau memberikan vaksinasi pada individu yang rentan. Namun, karantina dan vaksinasi skala besar juga mengakibatkan kerugian ekonomi. Oleh karena itu perlu dikaji kontrol yang optimal agar biaya yang dikeluarkan minimum, namun kontrol yang dilakukan tetap efektif untuk mengendalikan penyebaran Covid-1. Dalam penelitian ini dipelajari masalah pengendalian optimal epidemik yang dimodelkan melalui model SIR stokastik. Penyebaran Covid-19 diasumsikan dapat dikendalikan oleh pemerintah dengan pemberian kontrol vaksinasi dan isolasi dengan rtujuan meminimumkan jumlah individu terinfeksi dan biaya vaksinasi. Model dikonstruksikan menjadi 2 kasus yaitu model I dengan vaksinasi dan model II dengan isolasi. Model ini didekati dengan persamaan Hamilton-Jacobi-Bellman yang menghasilkan sistem persamaan diferensial stokastik maju mundur. Penyelesaian persamaan Hamilton-Jacobi-Bellman didekati dengan menggunakan prinsip stokastik maksimum. Berdasarkan hasil analisis kontrol vaksinasi pada model I dan model II keduanya eksis dan dengan menerapkan prinsip Stokastik maksimum dapat diperoleh kontrol dan sistem yang optimal.
\end{abstract}

Kata Kunci : Covid-19, Vaksinasi, Isolasi, Hamilton-Jacobi-Bellman, Prinsip Stokastik Maksimum.

\begin{abstract}
The spread of Covid-19 can be controlled by quarantine the population infected or vaccinating susceptible individuals. However, large-scale quarantines and vaccinations also result in economic losses. Therefore, optimal control is needed so that the required costs are minimum, but the controls carried out are still effective in controlling the spread of Covid-19. In this research, the problem of optimal epidemic control is studied which is modeled through the stochastic SIR model. The spread of Covid-19 is assumed to be controlled by the government by providing vaccination control and isolation which aims to minimize the number of infected individuals and the cost of vaccination. The model is constructed based on 2 cases, Model I with vaccination, and model II with isolation. This model is approximated by the Hamilton-Jacobi-Bellman equation which produces a system of back and forth stochastic differential equations. The solution to the Hamilton-Jacobi-Bellman equation is approached using the maximum stochastic principle. Based on the results of the analysis of vaccination control in a model I and model II both exist and by applying the maximum stochastic principle, the optimal control and system can be obtained.
\end{abstract}

Keywords: Covid-19, Vaccination, Isolation, Hamilton-Jacobi-Bellman, Maximum Stochastic Problems.

Article info:

Submitted: $18^{\text {th }}$ November $2020 \quad$ Accepted: $28^{\text {th }}$ April 2021

How to cite this article:

M. Pasaribu and H. Helmi, "APLIKASI PERSAMAAN DIFERENSIAL STOKASTIK PADA MASALAH KONTROL OPTIMUM BERKENDALA”, BAREKENG: J. Il. Mat. \& Ter., vol. 15, no. 02, pp. 257-266, Jun. 2021.

This work is licensed under a Creative Commons Attribution-ShareAlike 4.0 International License.

Copyright @ 2021 Meliana Pasaribu, Helmi Helmi 


\section{PENDAHULUAN}

Permasalahan penyakit menular merupakan hal yang harus segera diselesaikan. Hal ini karena penyakit menular dapat mengancam kehidupan. Penyakit menular dapat disebabkan oleh mikroogranisme patogen seperti bakteri, virus parasit atau jamur. Sampai saat ini banyak penyakit menular yang mewabah di dunia. Salah satu virus yang menyebabkan penyakit menular adalah virus Corona (Covid-19). Wabah Covid-19 yang mematikan dan menular disebabkan oleh SARS-CoV-2. Virus ini muncul pertama kali di Wuhan dan kota-kota lain di Cina pada akhir tahun 2019. Covid-19 telah menjadi pandemi global sebagaimana dinyatakan oleh Organisasi Kesehatan Dunia (WHO) pada kuartal pertama 2020[1].

Covid-19 diperkirakan masuk ke Indonesia pada pertengahan Februari 2020. Pada tanggal 13 April 2020, presiden Republik Indonesia menetapkan penyebaran Covid-19 sebagai bencana Nasional[2]. Ciri khas Covid-19 yang membuat sulit untuk ditangani adalah beragamnya periode inkubasi (dalam beberapa kasus lebih dari 14 hari) dan beberapa pasien tanpa gejala yang menular. Belum adanya obat dan vaksin yang tepat dalam penanganan Covid-19 serta mengingat sifat menular dari virus ini, kemungkinan bertambahnya kasus Covid-19 semakin tinggi. Oleh karena itu diperlukan suatu alat untuk mengontrol dan mengetahui penyebaran dari Covid-19. Salah satunya dengan model matematika yang memainkan peranan penting dalam meningkatkan pemahaman tentang mekanisme yang mempengaruhi penyebaran penyakit dan memberikan pedoman bagaimana penyebaran tersebut dapat dikendalikan[3],[4],[5].

Pemodelan matematika dengan menggunakan masalah kontrol optimal deterministik kemudian dieksplorasi secara luas dalam epidemiologi matematika. Beberapa penelitian [6],[7],[8] menunjukkan bahwa model epidemi yang dibangun dengan masalah kontrol optimal adalah tepat dan sangat berguna untuk menyarankan strategi kontrol dalam mengekang penyebaran penyakit. Namun yang menjadi permasalahan adalah terlalu banyak faktor acak dalam penyebaran Covid-19, tidak dapat diketahui dengan pasti jumlah individu yang terjangkit Covid-19, kondisi fisik yang berbeda tiap individu dan perubahan perilaku dari individu. Oleh karena itu aspek stokastik sangat menarik untuk diteliti. Dengan demikian perlu dikaji pemodelan matematika dengan masalah kontrol optimal stokastik.

Metode yang digunakan untuk mengontrol penyebaran adalah dengan mengkarantina penderita yang menjadi sumber utama penyebaran virus yakni populasi yang terinfeksi Covid-19 atau memberikan vaksinasi pada individu yang rentan. Pengalaman Cina pada Februari 2020-Maret 2020 menunjukkan bahwa karantina secara efektif dapat menghentikan penyebaran infeksi dan memusnahkan virus. Namun pada saat yang sama, karantina dan vaksinasi skala besar juga mengakibatkan kerugian ekonomi. Oleh karena itu perlu dikaji kontrol yang optimal agar biaya yang dikeluarkan minimum, namun kontrol yang dilakukan tetap efektif untuk mengendalikan penyebaran Covid-19.

Dalam penelitian ini dipelajari masalah pengendalian optimal epidemik yang dimodelkan melalui model SIR stokastik dengan berasumsi bahwa pemerintah memiliki kemampuan untuk mempengaruhi penyebaran Covid-19 melalui salah satu atau beberapa kebijakan. Model ini digunakan dalam epidemiologi matematika yang memperhatikan evolusi waktu dari penyebaran Covid-19. Permasalahan ini didekati dengan persamaan Hamilton-Jacobi-Bellman yang menghasilkan sistem persamaan diferensial stokastik maju mundur. Penyelesaian persamaan Hamilton-Jacobi-Bellman didekati dengan menggunakan prinsip stokastik maksimum.

\section{METODE PENELITIAN}

Dalam penelitian ini dipelajari masalah pengendalian optimal epidemik yang dimodelkan melalui model SIR stokastik dengan berasumsi bahwa pemerintah memiliki kemampuan untuk mempengaruhi penyebaran Covid-19 melalui salah satu atau beberapa kebijakan. Penelitian ini diawali dengan melakukan studi literatur dari beberapa referensi yang terkait dengan persamaan diferensial stokastik, kontrol optimal dan Covid-19. Setelah itu peneliti mempelajari tentang model SIR dari penyebaran Covid-19 dan melakukan perluasan model SIR stokastik. Hal ini dilakukan karena terlalu banyak faktor acak dalam penyebaran Covid-19, diantaranya kondisi fisik yang berbeda tiap individu dan perubahan perilaku dari individu. Oleh karena itu model SIR Deterministik diperluas dengan waktu kontinu stokastik. Selanjutnya dilakukan pengkonstruksian model penyebaran Covid-19. Pada permasalahan ini diasumsikan apabila seluruh populasi sudah melakukan vaksinasi maka herd immunity sudah terbentuk. Dengan demikian tidak perlu dilakukan isolasi. Dan asumsi selanjutnya apabila vaksin Covid-19 tidak tersedia, maka populasi 
diminta pemerintah untuk melakukan karantina/isolasi. Dengan asumsi tersebut, model dibagi ke dalam 2 kasus yaitu model I dengan vaksinasi dan model II dengan adanya isolasi. Model I dan II beserta fungsi objektifnya kemudian dianalisis dengan menerapkan Prinsip Stokastik Maksimum. Prinsip ini dilakukan terhadap Hamiltonian dari persamaan optimal yang terbentuk untuk menentukan kontrol optimalnya. Pendekatan ini merupakan versi stokastik dari Prinsip pontryagin maksimum yang diperkenalkan dalam kontrol optimal deterministik [9]. Langkah-langkahnya sebagai berikut:

Langkah 1 Membentuk fungsi pontryagin maksimum

$$
H(x, u, p, q)=\langle f(x, u), p\rangle-l(x, u)+\langle g(x), q\rangle
$$

Dengan $\langle\because, \cdot\rangle$ menunjukkan hasil kali dalam Euclidean, $\boldsymbol{p}=\left[\begin{array}{lll}p_{1} & p_{2} & p_{3}\end{array}\right]^{T}$ dan $\boldsymbol{q}=\left[\begin{array}{lll}q_{1} & q_{2} & q_{3}\end{array}\right]^{T}$ merupakan vektor adjoint.

Langkah 2: Meminimumkan $H$ terhadap vektor kontrol

dengan

$$
\begin{array}{r}
d x^{*}(t)=\frac{\partial H\left(x^{*}, u^{*}, p, q\right)}{\partial p} d t+g\left(x^{*}(t)\right) d w(t) \\
d \boldsymbol{p}(t)=\frac{-\partial H\left(x^{*}, u^{*}, p, q\right)}{\partial x} d t+\boldsymbol{q}(t) d w(t)
\end{array}
$$

$$
\begin{gathered}
x^{*}(0)=x_{0} \\
\boldsymbol{p}(T)=\frac{-\partial\left(x^{*}(T)\right)}{\partial x}
\end{gathered}
$$

dengan $x^{*}(t)$ merupakan lintasan optimal dari $x(t)$

Langkah 3: Membentuk fungsi

$$
\boldsymbol{p}(t)=\boldsymbol{\varphi}\left(t, x^{*}(t)\right)
$$

Dengan $\boldsymbol{\varphi}$ merupakan fungsi bernilai vektor dengan komponen $\varphi_{i}\left(t, x^{*}(t)\right)$ dengan $i=1,2,3$.

Langkah 4: Dengan menggunakan lemma itu, diperoleh

$$
\begin{aligned}
d \boldsymbol{\varphi}\left(t, x^{*}(t)\right)= & \left\{\frac{\partial \varphi_{i}\left(t, x^{*}(t)\right)}{\partial t}+\left\langle\frac{\partial \varphi_{i}\left(t, x^{*}(t)\right)}{\partial x}, f(x, u)\right\rangle+\frac{1}{2} \operatorname{tr}\left[\frac{\partial}{\partial x}\left(\frac{\partial \varphi_{i}}{\partial x}\right)^{T} g(x) g(x)^{T}\right]\right\} d t \\
& +\left\langle\frac{\partial \varphi_{i}(t, x(t))}{\partial x}, g(x)\right\rangle d w(t)
\end{aligned}
$$

Pada tahap selanjutnya dicari solusi numerik dari model I dan model II. Hal ini dilakukan dengan memanfaatkan persamaan diferensial stokastik maju mundur, dengan tujuan dapat diketahui dinamika perubahan jumlah populasi sebelum dilakukan kontrol dan jumlah populasi setelah dilakukan kontrol optimal. Langkah -langkahnya sebagai berikut:

Langkah 1: Menentukan nilai $\boldsymbol{\varphi}(t, x)$

Langkah 2: Gunakan $\boldsymbol{\varphi}(t, x)$ untuk menentukan nilai $\boldsymbol{p}(t)=\boldsymbol{\varphi}\left(t, x^{*}(t)\right)$

Langkah 3: Subtitusi $\boldsymbol{p}(t)$ dan $\boldsymbol{q}(t)$ ke Persamaan (1).

\section{HASIL DAN PEMBAHASAN}

\subsection{Pengkonstruksian Model Penyebaran Covid-19}

Populasi dibagi ke dalam tiga sub-populasi, yaitu individu rentan (susceptible), individu terinfeksi/sakit (infected), dan individu sembuh (Recovered). Sub-populasi tersebut masing-masing dilambangkan dengan $S$ untuk susceptible, I untuk infected, dan $R$ untuk Recovered. Pada permasalahan ini diasumsikan bahwa populasi bersifat tertutup, laju kelahiran sama dengan laju kematian, dan sub-populasi susceptible dapat terinfeksi jika melakukan kontak dengan sub-populasi infected. Selain itu setiap subpopulasi infectious memiliki probabilitas yang sama untuk menularkan virus Covid 19 ke setiap subpopulasi susceptible di dalam populasi. Berdasarkan asumsi-asumsi tersebut diperoleh model 


$$
\begin{aligned}
& \frac{d S}{d t}=\mu-\beta S I-\mu S+\theta R \\
& \frac{d I}{d t}=\beta S I-(\gamma+\mu) I \\
& \frac{d R}{d t}=\gamma I-(\mu+\theta) R
\end{aligned}
$$

dengan syarat awal $S(0)=S_{0}, I(0)=I_{0}, R(0)=R_{0}$. Dalam model tersebut $\mu, \beta, \theta, \gamma$ adalah konstantakonstanta positif. $\mu$ merupakan laju kelahiran per satuan waktu, $\beta$ merupakan laju kontak efektif per satuan waktu, $\theta$ merupakan laju reinfeksi dari $R$ ke $I$ per satuan waktu. Sedangkan $\gamma$ merupakan laju recovered dari kompartemen $I$ ke $R$ per satuan waktu. Dan $S+I+R=R$.

Permasalah kontrol optimal dalam pembahasan ini berkaitan dengan adanya asumsi bahwa pemerintah berperan penting sebagai pengendali penyebaran Covid-19 melalui vaksinasi individu yang rentan, dengan laju $v$. Hal ini mengakibatkan sebanyak $v S$ dari populasi yang rentan kebal terhadap Covid19. Serta isolasi individu yang terinfeksi dengan laju $i$. Akibatnya sebagian kecil dari populasi yang terinfeksi hilang dan mencegah penyebaran virus Covid-19.

Selama pandemi, tidak dapat diketahui dengan pasti jumlah individu per total populasi yang termasuk dalam kompartemen susceptible, infected, dan recovered. Akibatnya timbul reaksi panik dari populasi, sehingga mengisolasi semua populasi baik yang rentan terinfeksi maupun kebal. Selain itu juga adanya kondisi fisik yang berbeda tiap individu dan perubahan perilaku dari individu, maka ditambahkan aspek stokastik pada model SIR deterministik. Oleh karena itu, permasalahan (2) selanjutnya diperluas dengan waktu kontinu stokastik dari model SIR Deterministik dengan pemberian $W_{t}$ yang merupakan gerak Brownian Standar, dan $\dot{W}_{t}$ menunjukkan proses white noise. Dan anggap bahwa laju infeksi $\beta$ tergantung pada guncangan acak, $\beta_{t}=\beta+\sigma \dot{W}_{t}$ dengan $\sigma$ menunjukkan parameter volatilitas serta laju kesembuhan $\gamma$ tetap konstan. Dengan demikian diperoleh model SIR berikut

$$
\begin{gathered}
d S=(\mu-\beta S I-(\mu+v) S+\theta R) d t-\sigma I S d W_{t} \\
d I=(\beta S I-(\gamma+\mu+i) I) d t+\sigma I S d W_{t} \\
d R=((\gamma+i) I-(\mu+\theta) R+v S) d t
\end{gathered}
$$

Dengan syarat awal $S(0)=S_{0}, I(0)=I_{0}, R(0)=R_{0}$.

\subsection{Masalah Kontrol Optimal Stokastik}

Berdasarkan asumsi-asumsi yang telah dibentuk, dilakukan pengkonstruksian Kontrol Optimal beserta syarat-syaratnya. Pada penelitian ini diharapkan mendapatkan kontrol (vaksinasi atau isolasi) optimal. Hal ini dilakukan dengan cara meminimumkan jumlah populasi Infected dan juga meminimumkan biaya kontrol (vaksinasi). Secara matematis permasalahan ini adalah meminimalkan fungsi Objektif berikut [9].

$$
J=E\left(\int_{0}^{T} l(x(t), u(t)) d t+h(x(T))\right)
$$

dengan $u(t)$ adalah fungsi peubah kontrol yang nilainya terdapat dalam himpunan bagian tertutup $\mathbb{R}^{m}$, peubah $x(t)$ merupakan state, $E$ melambangkan nilai harapan, T menyatakan lamanya program vaksinasi atau isolasi, serta $: \mathbb{R}^{3} \times \mathbb{R}^{1} \rightarrow \mathbb{R}^{1}$ dan $h: \mathbb{R}^{3} \rightarrow \mathbb{R}$ fungsi terdiferensial kontinu. Dalam penelitian ini dipelajari masalah kontrol optimal untuk menemukan kebijakan optimal $u^{*} \in \mathcal{U}$ sehingga

$$
J\left(u^{*}\right) \leq J(u), \forall u \in \mathcal{U}
$$

Dengan $\mathcal{U}$ merupakan himpunan kontrol admissible yang dapat didefinisikan oleh

$$
\mathcal{U}=\left\{u \mid 0 \leq u(t) \leq C_{p}, \forall t \in \Theta \equiv(0, T)\right\} .
$$

Tujuan dari pengendalian infeksi adalah untuk mengurangi populasi terinfeksi dan mengurangi populasi yang rentan serta mengurangi efek samping dari kontrol. 


\subsection{Prinsip Stokastik Maksimum}

Didefinisikan vektor

$$
\boldsymbol{x}(t)=\left[\begin{array}{l}
x_{1}(t) \\
x_{2}(t) \\
x_{3}(t)
\end{array}\right] \equiv\left[\begin{array}{l}
S(t) \\
I(t) \\
R(t)
\end{array}\right]
$$

Persamaan (3) menjadi

$$
d \boldsymbol{x}(t)=\boldsymbol{f}(x(t), u(t)) d t+\boldsymbol{g}(x(t)) d W_{t}
$$

Dengan syarat awal

$$
\boldsymbol{x}(0)=\left[\begin{array}{l}
S(0) \\
I(0) \\
R(0)
\end{array}\right]
$$

Dengan fungsi $\boldsymbol{f}$ dan $\boldsymbol{g}$ merupakan fungsi bernilai vektor dengan komponen

$$
\begin{aligned}
& f_{1}=\mu-\beta x_{1} x_{2}-(\mu+v) x_{1}+\theta x_{3} \\
& f_{2}=\beta x_{1} x_{2}-(\gamma+\mu+i) x_{2} \\
& f_{3}=(\gamma+i) x_{2}-(\mu+\theta) x_{3}+v x_{1}
\end{aligned}
$$

dengan

$$
\begin{aligned}
& g_{1}=-\sigma x_{1} x_{2} \\
& g_{2}=\sigma x_{1} x_{2} \\
& g_{3}=0
\end{aligned}
$$

Didefinisikan fungsi Hamiltonian

$$
H(x, u, p, q)=\langle\boldsymbol{f}(\boldsymbol{x}, u), p\rangle-l(\boldsymbol{x}, u)+\langle\boldsymbol{g}(\boldsymbol{x}), q\rangle
$$

Dengan $\langle\cdot, \cdot\rangle$ menunjukkan hasil kali dalam Euclidean, $\boldsymbol{p}=\left[\begin{array}{lll}p_{1} & p_{2} & p_{3}\end{array}\right]^{T}$ dan $\boldsymbol{q}=\left[\begin{array}{lll}q_{1} & q_{2} & q_{3}\end{array}\right]^{T}$ merupakan vektor adjoint [10]. Sesuai Prinsip Maksimum Stokastik

$$
\begin{gathered}
d \boldsymbol{x}^{*}(t)=\frac{\partial H\left(\boldsymbol{x}^{*}, \boldsymbol{u}^{*}, \boldsymbol{p}, \boldsymbol{q}\right)}{\partial \boldsymbol{p}} d t+\boldsymbol{g}\left(\boldsymbol{x}^{*}(t)\right) d w(t) \\
d \boldsymbol{p}(t)=\frac{-\partial H\left(\boldsymbol{x}^{*}, \boldsymbol{u}^{*}, \boldsymbol{p}, \boldsymbol{q}\right)}{\partial \boldsymbol{x}} d t+\boldsymbol{q}(t) d w(t) \\
H\left(\boldsymbol{x}^{*}, \boldsymbol{u}^{*}, \boldsymbol{p}, \boldsymbol{q}\right)=\max _{u \in \mathcal{U}} H\left(\boldsymbol{x}^{*}, \boldsymbol{u}, \boldsymbol{p}, \boldsymbol{q}\right)
\end{gathered}
$$

dengan

$$
\begin{gathered}
\boldsymbol{x}^{*}(0)=\boldsymbol{x}_{0} \\
\boldsymbol{p}(T)=\frac{-\partial\left(\boldsymbol{x}^{*}(T)\right)}{\partial \boldsymbol{x}}
\end{gathered}
$$

dengan $\boldsymbol{x}^{*}(t)$ merupakan lintasan optimal dari $\boldsymbol{x}(t)$.

\subsection{Penyelesaian Kontrol Optimal Vaksinasi}

Pada model ini, seluruh populasi diasumsikan sudah melakukan vaksinasi sehingga sudah membentuk herd immunity. Dengan demikian $u_{2}=0$, akibatnya persamaan (3) menjadi

$$
\begin{gathered}
d S=(\mu-\beta S I-(\mu+u(t)) S) d t-\sigma I S d W_{t} \\
d I=(\beta S I-(\gamma+\mu) I) d t+\sigma I S d W_{t} \\
\quad d R=(\gamma I-\mu R+u(t) S) d t
\end{gathered}
$$


Karena jumlah populasi konstan maka $R=1-S-I$. Dengan demikian diperoleh

$$
\begin{gathered}
x(t)=\left[\begin{array}{cc}
x_{1}(t) & x_{2}(t)
\end{array}\right]^{T}=\left[\begin{array}{ll}
S(t) & I(t)
\end{array}\right]^{T} \\
f_{1}=\mu-\beta x_{1} x_{2}-(\mu+u(t)) x_{1} \\
f_{2}=\beta x_{1} x_{2}-(\gamma+\mu) x_{2} \\
\text { dengan } g_{1}=-\sigma x_{1} x_{2} \\
g_{2}=\sigma x_{1} x_{2}
\end{gathered}
$$

Fungsi tujuan diberikan oleh

$$
J(u)=\frac{1}{2} E\left\{\int_{0}^{T}\left(\left(m x_{1}{ }^{2}(t)+n x_{2}{ }^{2}(t)+r u^{2}(t)\right) d t+k_{1} x_{1}{ }^{2}(T)+k_{2} x_{2}{ }^{2}(T)\right\}\right.
$$

dengan $m, n, r, k_{1}, k_{2}$ konstanta positif.

Teorema 1 Diketahui kontrol optimal $u(t)$ dan solusi optimal $S^{*}, I^{*}, R^{*}$ dari sistem (4) maka terdapat variabel variabel adjoint yang memenuhi

$$
\begin{gathered}
d x_{1}=\left(\mu-\beta x_{1} x_{2}-(\mu+u(t)) x_{1}\right) d t-\sigma x_{1} x_{2} d W_{t} \\
d x_{2}=\left(\beta x_{1} x_{2}-(\gamma+\mu) x_{2}\right) d t+\sigma x_{1} x_{1} d W_{t} \\
d p_{1}=\left\{p_{1}(\mu+u(t))+\beta p_{1} x_{2}-\beta p_{2} x_{1}+m x_{1}+\sigma q_{1} x_{2}-\sigma q_{2} x_{2}\right\} d t+q_{1} d W_{t} \\
d p_{2}=\left\{\beta p_{1} x_{1}-\beta p_{2} x_{1}+(\gamma+\mu) p_{2}+n x_{2}+\sigma q_{1} x_{1}-\sigma q_{2} x_{1}\right\} d t+q_{2} d W_{t}
\end{gathered}
$$

Dengan syarat awal dan syarat batas

$$
\begin{gathered}
x_{1}(0)=S_{0}, x_{2}(0)=I_{0} \\
P_{1}(T)=-k_{1} x_{1}, P_{2}(T)=-k_{2} x_{2}
\end{gathered}
$$

Dan kontrol optimal $U(t)$ yaitu

$$
U(t)=\max \left\{\min \left\{\frac{-\varphi_{1}(t, x(t))}{r}, x_{1}(t), C_{p}\right\}, 0\right\}
$$

Bukti: Diketahui kontrol optimal $u(t)$ dan solusi optimal $S^{*}, I^{*}, R^{*}$ dari sistem (4) maka terdapat variabel variabel adjoint. Berdasarkan prinsip stokastik maksimum diperoleh

$$
\begin{gathered}
d x_{1}=\left(\mu-\beta x_{1} x_{2}-(\mu+u(t)) x_{1}\right) d t-\sigma x_{1} x_{2} d W_{t} \\
d x_{2}=\left(\beta x_{1} x_{2}-(\gamma+\mu) x_{2}\right) d t+\sigma x_{1} x_{1} d W_{t} \\
d p_{1}=\left\{p_{1}(\mu+u(t))+\beta p_{1} x_{2}-\beta p_{2} x_{1}+m x_{1}+\sigma q_{1} x_{2}-\sigma q_{2} x_{2}\right\} d t+q_{1} d W_{t} \\
d p_{2}=\left\{\beta p_{1} x_{1}-\beta p_{2} x_{1}+(\gamma+\mu) p_{2}+n x_{2}+\sigma q_{1} x_{1}-\sigma q_{2} x_{1}\right\} d t+q_{2} d W_{t} \\
U(t)=\max \left\{\min \left\{\frac{-p_{1}(t)}{r}, x_{1}(t), C_{p}\right\}, 0\right\}
\end{gathered}
$$

Dengan syarat awal dan syarat batas

$$
\begin{gathered}
x_{1}(0)=S_{0}, x_{2}(0)=I_{0} \\
P_{1}(T)=-k_{1} x_{1}, P_{2}(T)=-k_{2} x_{2}
\end{gathered}
$$

Definisikan fungsi

$$
p_{I}(t)=\varphi_{I}(t, x(t))
$$

Dengan menggunakan persamaan diferensial stokastik maju mundur diperoleh 


$$
\begin{gathered}
\frac{\partial \varphi_{1}(t, x)}{\partial t}+\frac{\partial \varphi_{1}(t, x)}{\partial x_{1}}\left(\mu-\beta x_{1} x_{2}-(\mu+u(t)) x_{1}\right)+\frac{\partial \varphi_{1}(t, x)}{\partial x_{2}}\left(\beta x_{1} x_{2}-(\gamma+\mu) x_{2}\right) \\
+\frac{1}{2} \sigma^{2} x_{1}{ }^{2} x_{2}{ }^{2}\left(\frac{\partial}{\partial x_{1}}-\frac{\partial}{\partial x_{2}}\right)^{2} \varphi_{1}(t, x)-\varphi_{1}(t, x)(\mu+u(t))-\beta x_{2}\left(\varphi_{1}(t, x)-\varphi_{2}(t, x)\right) \\
\quad-m x_{1}+\sigma^{2} x_{1} x_{2}{ }^{2} x_{2}\left(\frac{\partial}{\partial x_{1}}-\frac{\partial}{\partial x_{2}}\right)\left(\varphi_{1}(t, x)-\varphi_{1}(t, x)\right)=0 \\
\frac{\partial \varphi_{2}(t, x)}{\partial t}+\frac{\partial \varphi_{2}(t, x)}{\partial x_{1}}\left(\mu-\beta x_{1} x_{2}-(\mu+u(t)) x_{1}\right)+\frac{\partial \varphi_{2}(t, x)}{\partial x_{2}}\left(\beta x_{1} x_{2}-(\gamma+\mu) x_{2}\right) \\
+\frac{1}{2} \sigma^{2} x_{1}{ }^{2} x_{2}{ }^{2}\left(\frac{\partial}{\partial x_{1}}-\frac{\partial}{\partial x_{2}}\right)^{2} \varphi_{2}(t, x)-\beta \varphi_{1} x_{1}-\beta \varphi_{2} x_{1}-(\gamma+\mu) \varphi_{2}-n x_{2} \\
+\sigma^{2} x_{1}{ }^{2} x_{2}\left(\frac{\partial}{\partial x_{1}}-\frac{\partial}{\partial x_{2}}\right)\left(\varphi_{1}(t, x)-\varphi_{1}(t, x)\right)=0
\end{gathered}
$$

Dengan $u(t)$ diperoleh dari

$$
u(t)=\max \left\{\min \left\{\frac{-\varphi_{1}(t, x(t))}{r}, x_{1}(t), C_{p}\right\}, 0\right\}
$$

Dengan syarat

$$
\varphi_{1}(T, x)=-k_{1} x_{1}, \varphi_{2}(T, x)=-k_{2} x_{2}
$$

\subsection{Penyelesaian Kontrol Optimal Isolasi}

Dalam hal ini vaksin Covid-19 tidak tersedia, akibatnya $u_{1}=0$. Dengan demikian persamaan (3) menjadi:

$$
\begin{gathered}
d S=(\mu-\beta S I-\mu S) d t-\sigma I S d W_{t} \\
d I=(\beta S I-(\gamma+\mu+u(t)) I) d t+\sigma I S d W_{t} \\
d R=((\gamma+u(t)) I-\mu R) d t
\end{gathered}
$$

Karena jumlah populasi konstan maka $S=1-I-R$.

dengan

$$
\begin{gathered}
x(t)=\left[\begin{array}{ll}
x_{2}(t) & x_{3}(t)
\end{array}\right]^{T}=\left[\begin{array}{ll}
I(t) & R(t)
\end{array}\right]^{T} \\
f_{2}=\beta x_{1} x_{2}-(\gamma+\mu+u(t)) x_{2} \\
f_{3}=(\gamma+u(t)) x_{2}-\mu x_{3}
\end{gathered}
$$

$$
\begin{gathered}
g_{2}=\sigma x_{1} x_{2} \\
g_{3}=0 \\
J(u)=\frac{1}{2} E\left\{\int_{0}^{T}\left(\left(a x_{2}{ }^{2}(t)+b x_{3}{ }^{2}(t)+c u^{2}(t)\right) d t+k_{3} x_{2}{ }^{2}(T)+k_{4} x_{3}{ }^{2}(T)\right\}\right.
\end{gathered}
$$

Dengan $a, b, c, k_{2}, k_{3}$ konstanta positif.

Teorema 2 Diketahui kontrol optimal $u(t)$ dan solusi optimal $S^{*}, I^{*}, R^{*}$ dari sistem (4) maka terdapat variabel variabel adjoint yang memenuhi

$$
\begin{gathered}
d x_{2}=\left(\beta x_{1} x_{2}-(\gamma+\mu+u(t)) x_{2}\right) d t+\sigma x_{1} x_{2} d W_{t} \\
d x_{3}=\left((\gamma+u(t)) x_{2}-\mu x_{3}\right) d t \\
d p_{2}=\left\{\beta p_{3} x_{1}-\beta p_{2} x_{1}+(\gamma+\mu+u(t)) p_{2}+a x_{2}+\sigma q_{2} x_{1}-\sigma q_{3} x_{1}\right\} d t+q_{2} d W_{t} \\
d p_{3}=\left\{\mu p_{2}-\mu p_{3}+b x_{3}\right\} d t+q_{2} d W_{t}
\end{gathered}
$$

Dengan syarat awal dan syarat batas

$$
x_{2}(0)=I_{0}, x_{3}(0)=R_{0}
$$


Dan kontrol optimal $U(t)$ yaitu

$$
p_{2}(T)=-k_{3} x_{2}, p_{2}(T)=-k_{4} x_{3}
$$

$$
u(t)=\max \left\{\min \left\{\frac{-\varphi_{2}(t, x(t))}{r}, x_{2}(t), C_{p}\right\}, 0\right\}
$$

Bukti: Diketahui kontrol optimal $u(t)$ dan solusi optimal $S^{*}, I^{*}, R^{*}$ dari sistem (4) maka terdapat variabel variabel adjoint. Berdasarkan prinsip stokastik maksimum diperoleh:

$$
\begin{gathered}
d x_{2}=\left(\beta x_{1} x_{2}-(\gamma+\mu+u(t)) x_{2}\right) d t+\sigma x_{1} x_{2} d W_{t} \\
d x_{3}=\left((\gamma+u(t)) x_{2}-\mu x_{3}\right) d t \\
d p_{2}=\left\{\beta p_{3} x_{1}-\beta p_{2} x_{1}+(\gamma+\mu+u(t)) p_{2}+a x_{2}+\sigma q_{2} x_{1}-\sigma q_{3} x_{1}\right\} d t+q_{2} d W_{t} \\
d p_{3}=\left\{\mu p_{2}-\mu p_{3}+b x_{3}\right\} d t+q_{2} d W_{t} \\
U(t)=\max \left\{\min \left\{\frac{-p_{2}(t)}{r}, x_{2}(t), C_{p}\right\}, 0\right\}
\end{gathered}
$$

Dengan syarat awal dan syarat batas

Definisikan fungsi

$$
\begin{gathered}
x_{2}(0)=I_{0}, x_{3}(0)=R_{0} \\
p_{2}(T)=-k_{3} x_{2}, p_{2}(T)=-k_{4} x_{3}
\end{gathered}
$$

$$
p_{2}(t)=\varphi_{2}(t, x(t))
$$

Dengan menggunakan persamaan diferensial stokastik maju mundur diperoleh

$$
\begin{gathered}
\frac{\partial \varphi_{2}(t, x)}{\partial t}+\frac{\partial \varphi_{2}(t, x)}{\partial x_{2}}\left(\beta x_{1} x_{2}-(\gamma+\mu+u(t)) x_{2}\right)+\frac{\partial \varphi_{2}(t, x)}{\partial x_{3}}\left((\gamma+u(t)) x_{2}-\mu x_{3}\right) \\
+\frac{1}{2} \sigma^{2} x_{2}{ }^{2} x_{3}{ }^{2}\left(\frac{\partial}{\partial x_{2}}-\frac{\partial}{\partial x_{3}}\right)^{2} \varphi_{2}(t, x)+\beta x_{1}\left(\left(\varphi_{2}(t, x)-\varphi_{3}(t, x)\right)\right) \\
-(\gamma+\mu+u(t)) \varphi_{2}(t, x)-a x_{2}+\sigma^{2} x_{2} x_{3}{ }^{2}\left(\frac{\partial}{\partial x_{2}}-\frac{\partial}{\partial x_{3}}\right)\left(\varphi_{2}(t, x)-\varphi_{3}(t, x)\right)=0 \\
\frac{\partial \varphi_{3}(t, x)}{\partial t}+\frac{\partial \varphi_{3}(t, x)}{\partial x_{2}}\left(\beta x_{1} x_{2}-(\gamma+\mu+u(t)) x_{2}\right)+\frac{\partial \varphi_{3}(t, x)}{\partial x_{3}}\left((\gamma+u(t)) x_{2}-\mu x_{3}\right)-\mu \varphi_{3}-b x_{3} \\
+\sigma^{2} x_{3}{ }^{2} x_{2}\left(\frac{\partial}{\partial x_{2}}-\frac{\partial}{\partial x_{3}}\right)\left(\varphi_{2}(t, x)-\varphi_{3}(t, x)\right)=0
\end{gathered}
$$

Dengan $u(t)$ diperoleh dari

Dengan syarat

$$
u(t)=\max \left\{\min \left\{\frac{-\varphi_{2}(t, x(t))}{r}, x_{2}(t), C_{p}\right\}, 0\right\}
$$

$$
\varphi_{2}(T, x)=-k_{3} x_{2}, \varphi_{3}(T, x)=-k_{4} x_{3} .
$$

\section{KESIMPULAN}

Berdasarkan hasil penelitian diperoleh kesimpulan bahwa kontrol optimal berkaitan dengan tindakan vaksinasi atau isolasi dengan meminimalkan jumlah populasi Infected dan biaya kontrol (vaksinasi). Kontrol yang optimal dari permasalahan pada Teorema (1) dan Teorema (2) dapat ditentukan dengan menerapkan prinsip Stokastik maksimum.

\section{UCAPAN TERIMA KASIH}

Penulis berterimakasih kepada LPPKM Universitas Tanjungpura atas bantuan DANA DIPA UNTAN Tahun anggaran 2020 Sesuai dengan Surat Keputusan Rektor UNTAN No. SK. DIPA023.17.2.677517/2020 tanggal 27 Desember 2019. 


\section{DAFTAR PUSTAKA}

[1] World Health Organization. WHO Characterizes COVID-19 as a pandemic, 2020. https://www.who.int/dg/speeches/detail/who-director-general-opening-remarks-at-the-media-briefing-on-covid-19-11 march 2020

[2] Keputusan Presiden RI No. 12 Tahun 2020 tentang penetapan Bencana Non Alam Penyebaran Virus Corona sebagai Bencana Nasional. 13 April 2020

[3] C. I. Siertos and L. Russo. Mathematical modelling of Infectious disease dynamics. Virulence. 4(4): 295-306, 2013

[4] F. Brauer. Mathematical epidemiology: Past, present and future. Infectious Disease Modelling, 2(2):113-127:2017

[5] H. W. Hethcote. The mathematics of Infectious Disease. SIAM review, 42(4): 599-653, 2000.

[6] E. V. Grigorieva, E. N. Khailov and A. Korobeinikov. Optimal quarantine strategies for COVID-19 Control Models. arXiv preprint arXiv:2004.10614v2, 2020.

[7] E. Okyere, J. D. Ankamah, A. K. Hunkpe, and D. Mensah. Deterministic epidemic models for ebola infection with timedependent controls. arXiv preprint arXiv:1908.07974, 2019.

[8] S. Olaniyi, K. Okosuh, S. O. Adesanya, and E. A. Areo. Global Stability and optimal control analysis of malaria dynamics in the presence of human travels. The Open Infectious Disease Journal, 10(10), 2018.

[9] E. Syahril, 1991, A Maximum Principle in Stochastic Optimal Control, Graduate Diploma Project, Department of Applied Mathematics, The University of Adelaide, Adelaide

[10] Buldaev A.S, Burlakov, I. D, and Anakhin V.D. Pertubation Methods for Maximum Principle in Optimal Control Problem. Advances in Intelligent Systems Research, 164.

[11] A. Lesniewski. Epidemic Control via Stochastic Optimal Control. arXiv preprint arXiv:2004.06680v3, 2020 
